\title{
REAL-LIFE APPROACHES EMPLOYED BY RECOGNIZED GOVERNMENTS TO ENSURE HEALTH COVERAGE OF CITIZENS IN FRAGILE SETTINGS, INCLUDING THE POPULATION OF THE DISPUTED TERRITORIES, STRUGGLING FOR INDEPENDENCE
}

DOI: 10.36740/WLek202105141

\author{
Yashchenko V. Mariia, Yurochko P. Tetiana \\ NATIONAL UNIVERSITY OF "KYIV-MOHYLA ACADEMY", KYIV, UKRAINE
}

\begin{abstract}
The aim: To review real-life approaches employed by recognized governments to ensure health coverage of citizens in fragile settings, including the population of the disputed territories, struggling for independence.

Materials and methods: Content analysis of documents, the peer-reviewed articles, open-access databases, policy documents and original sources were utilized in order to archive the study aim. Multidimensional approach to source selection was chosen for objective assessment of the current policy- and decision-making practices.

Conclusions: Protracted nature of conflict leads to health system fragility resulting in adverse effects on conflict-affected population health coverage. Health policy in such settings is often externally-driven due to lack of capacities of recognized government and reliance on external funding. Safety and political concerns impede imposition of the context-specific durable solutions for the universal health coverage. Recognized governments lack access to real data to perform evidence-based decision-making. Conventional decision-making based on external demand leads to permanent underperformance of health governance.
\end{abstract}

KEY WORDS: Conflict and health, public health policy, evidence-based decision-making

Wiad Lek. 2021;74(5):1268-1273

\section{INTRODUCTION}

In the preamble to the Constitution of the World Health Organization, the participating countries agree that "The health of all peoples is fundamental to the attainment of peace and security and is dependent upon the fullest cooperation of individuals and States.", and in turn "Governments have a responsibility for the health of their peoples which can be fulfilled only by the provision of adequate health and social measures". Thus, states are committed to creating conditions for effective and accessible health care for all citizens [1].

The best way to provide health care and medical services to anyone, anywhere, and the most effective way to achieve health for all primary care as has been recognized by States Parties after defining the principles of primary care in Alma-Ata in 1978 [2] and their review and approval in Astana in 2018 [3]. These documents led to a global rethinking of healthcare delivery and became a framework for States Parties ' execution of healthcare reforms to cover the majority of a person's health needs throughout their life including prevention, treatment, rehabilitation and palliative care [3]. Such health care reform is an ambitious task for countries with limited resources, and it is difficult to implement even in peacetime, as a result in 2019 this coverage was not fulfilled for half of the people [3].

The health care system, which exists among the factors that affect safety and therefore cannot improve or maintain the health of the population, exists in special conditions and differs in resource-intensive, labor-intensive and management methods from the system in stable conditions. A relatively new term for global health, "fragile settings," has been introduced to describe this phenomenon [4]. This term refers to the socio-political conditions under which changes for the better in the health of the population, made possible by advances in technology and governance, can be slowed down or even reversed, as well as to denote conditions that generate gaps in public health, provision of services, use of services and access to them. By definition, the types of such conditions are also armed conflict, in particular, protracted armed conflict, war and post-conflict reconstruction. In fact, during the crisis, resources and infrastructure naturally suffer, sometimes leaving only $10 \%$ of pre-war opportunities, and the population's need for medical care is growing naturally [5]. It is important to note that in 2013 , one in six people on the planet lived in fragile and post-conflict conditions [6]. A large body of literature sought to provide international actors with the evidence base for the humanitarian and development response to the armed conflicts in the health sector. However, there is a knowledge gap of real-life approaches employed by recognized governments to ensure health coverage of citizens, in particular, for the population of the disputed territories, struggling for independence. 


\section{THE AIM}

To review real-life approaches employed by recognized governments to ensure health coverage of citizens in fragile settings, including the population of the disputed territories, struggling for independence.

\section{MATERIALS AND METHODS}

Research design. Qualitative, descriptive desk study, comparative policy analysis.

Study structure. The study consisted of three subsequent stages. Firstly, the selection of study objects. For the purposes of this research the following criteria were applied to determine the sample: 1 . The disputed territory is defined as a region or autonomous province that is struggling for independence from a country to which the disputed territory belonged prior to the conflict. 2. There was an ongoing armed conflict over the disputed territory in 2020. 3. Presence of the de-facto government on the disputed territory. These criteria were chosen predominantly to obtain state-of-the-art knowledge compatible with the current health policies concerning armed conflict in Eastern Ukraine. Moreover, these criteria serve the idea of utilizing accessible information for understanding logic of policymaking in diverse settings.

Methods. Content analysis of documents, the peer-reviewed articles, open-access databases, policy documents and original sources were utilized in order to archive the study aim. Multidimensional approach to source selection was chosen for objective assessment of the current poli$c y-$ and decision-making practices. For each domain the official governmental source (legislative act, policy paper, official report etc.) was primarily retrieved. Supplementary information was collected from official sources of international agencies. Information from media sources and peer-reviewed articles was utilized to fill gaps in official data and support interpretation.

\section{REVEW AND DISCUSSION}

As definition of the armed conflict remains an issue and is extensively debated [7], for the purpose of this review the conflict is treated as ongoing if mentioned in at least two of three chosen sources - the monitoring news source "Wars in the word" and Uppsala Conflict Data Program data for 2019.

The primary list of countries and territories struggling for independence was retrieved from news monitoring source Wars in the word. An updated "List of ongoing conflicts" displays in total 46 Regions and autonomous provinces that are struggling for Independence. [8].

Since none of these armed conflicts started in 2018 and 2019, the Uppsala Conflict Data Program data for 2019 was used for additional verification. 12 conflicts of the primary list were verified and 1 additional item for analysis added [9].

Henceforth, for further selection only coinciding 13 territories of interest were chosen.
The search on presence of the de-facto government on the territory was conducted separately for each of 13 territories. The main criterium of this search was that the de-facto government should claim independence from the country, to which the disputed territory belonged prior to the conflict. 6 of 13 territories were chosen in process (see Table 1): Ambazonia (Cameroon), Somaliland (Somalia), Darfur (Sudan) European Federated States of Novorossia formed by the union of Self-proclaimed Donetsk People's Republic and Self-proclaimed Luhansk People's Republic (Ukraine), Artsakh/Nagorno-Karabakh (Armenia, Azerbaijan), occupied territories of Palestine (Israel).

The chosen conflicts have similarities in the protracted or potentially protracted nature of the conflict. As there is no agreed definition of the protracted conflict, but there is a common understanding of criteria of longevity, intractability and mutability [10]. The current conflict in Somalia started in 2009 [11], hostilities in Sudan (Darfur) - in 2003 [12], in Ukraine (European Federated States of Novorossia formed by the union of Self-proclaimed Donetsk People's Republic and Self-proclaimed Luhansk People's Republic) - in 2014 [13], Artsakh/Nagorno-Karabakh (Armenia, Azerbaijan) - in 1988 [14], occupied territories of Palestine (Palestine) in 1948 [15]. Despite the dispute over Ambazonia in Cameroon starting in 2017 [16], the political prelude to the conflict [17] and its intractability may lead to its potentially protracted nature.

For each of these countries, except Artsakh/Nagorno-Karabakh (Armenia, Azerbaijan) as the conflict over this territory escalated in autumn 2020 [18], [19], the United Nations Office for the Coordination of $\mathrm{Hu}-$ manitarian Affairs developed the Humanitarian Response Plan in 2019. All these Humanitarian Response Plans included health component to a different extend as any humanitarian crisis represents a critical threat to the health of the population [20] which means, that the recognized government is not able to cover humanitarian needs in health coverage of the civil population residing in the area of interest. As the information of the scope of the health emergency is not accessible for Artsakh/Nagorno-Karabakh (Armenia, Azerbaijan), this territory was excluded from the further analysis.

For Somalia the WHO assigned the Grade 3 of emergency with massive public health ramifications and declared need for vast involvement of the agency in the health crisis management [21].

In Somalia 3,15 million were deemed in need and 2,5 million people`s humanitarian needs for health were to be covered by the Humanitarian Response Plan in 2020 [22]. However, the Essential Package of Health Services was launched in 2014 in Somalia with particular attention to maternal, reproductive, neonatal and child health; common communicable diseases, HIV, sexually transmitted infections, tuberculosis; improvement of surveillance and control; provision of first aid and care of injured and ill [23]. The goal of universal basic health care by 2016 [24] was not attained as the UHC service coverage index in Somalia remains extremely low - 25 points [25]. 
Table 1. Territories selected for analysis

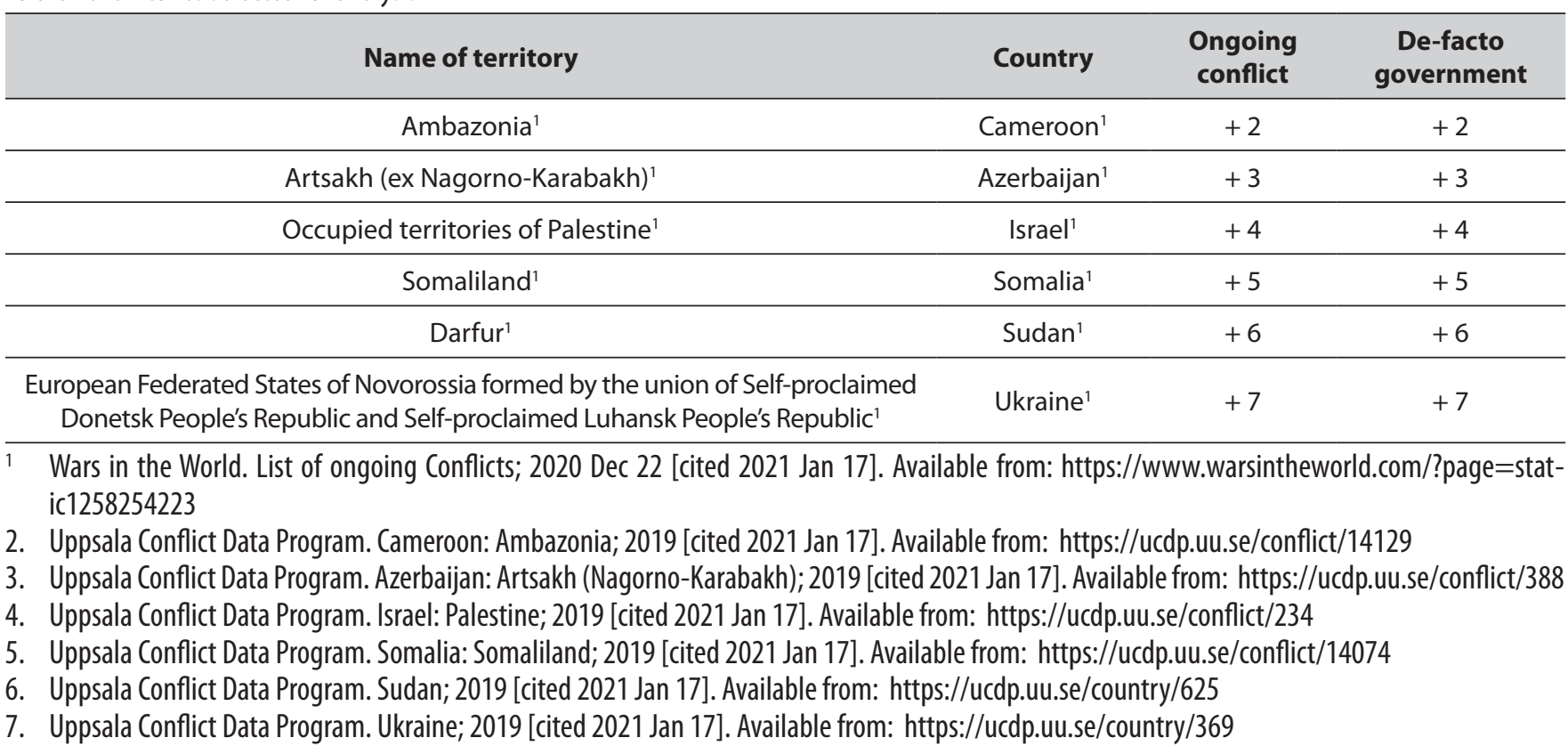

In 2019 Cabinet of Ministers of the Federal Government of Somalia adopted a National Development Plan (20202024) aiming to reduce poverty through political measures involving large external debt relief. This plan includes a section on the Health sector, and states that it is planned to develop legislation and regulation to endorse standards of care in public (almost funded externally, the last estimation \$10-12 per capita) and private sectors. Essential Health Services Packages will be complemented by the Reproductive, Maternal, Neonatal, Child and Adolescent Health Strategy [26].

As of 2017, both Somalia monitored the progress of their national health policy/strategy/plan towards Universal Health coverage [27] and did not pass legislation on Universal Health coverage [29].

For Sudan, Cameroon, Ukraine and Palestine the Grade 2 of emergency was assigned meaning moderate public health sequela and need for moderate international involvement for covering gaps in healthcare assurance [21].

In Sudan 8,62 million were deemed in need and 5,03 million people's humanitarian needs for health were to be covered by the Humanitarian Response Plan in 2020 [29]. The core priorities of the humanitarian health in Sudan are the promptness of response to multiple health emergencies, ensuring equitable access to humanitarian healthcare services, and building local capacities for the provision of the continuum of care, resilience and risk mitigation.

Throughout the conflict, healthcare capacities, both service and managerial, declined steadily. Not only Sudan shows particularly low UHC service coverage index - 44 [25], but there is a considerable inequality in access to care that is already scarce. Less than a half of health facilities are supplied with the essential pharmaceuticals, only one third can deliver primary healthcare services [29].

Sudan's health system is deteriorated and faces numerous challenges on multiple levels. Its health system `s capacity is undermined by external political and internal instability. In this turmoil the health system evolved from declaring free of charge service for all through privatization to the health insurance fund system [30]. As of 2017, Sudan monitored the progress of their national health policy/ strategy/plan towards Universal Health coverage [27] and did not pass legislation on Universal Health coverage [28].

In Cameroon 2,6 million were deemed in need and 1,2 million people's humanitarian needs for health were to be covered by the Humanitarian Response Plan in 2020 [31]. In the zone of conflict, efforts to ensure health coverage were made by both government and humanitarian agencies. The role of community health workers established to provide basic care, the systems of collecting vaccines and therapy for chronic diseases were adjusted for access to care for the internally displaced and patients receiving care out of region. These achievements are not enough to ensure proper health coverage as the gap in health system strengthening is created, on the one hand, by humanitarian agencies withdrawing staff and assistance from risk zones and, on the other hand, by government restricting the humanitarian organization in aid provision. Moreover, these joint efforts are limited and not countrywide [32].

To address the issue of Universal Health Coverage on a country level, the government tried different financial strategies, including, but not limited to the promotion of free care policies and insurance. Strategies of governance for Universal Health Coverage employed different scenarios of one, two or multiple local governing bodies [33]. On the contrary, Cameroon neither passed legislation on Universal Health coverage [28], nor monitored the progress of their national health policy/strategy/plan towards Universal Health coverage as of 2017 [27], conversely, this country shows the lowest UHC service coverage index in this group - 46 [25].

In Occupied Palestinian Territories 1,3 million were deemed in need and 800 thousand people's humanitarian 
needs for health were to be covered by the Humanitarian Response Plan in 2020 [34]. Occupation, fragmentation of territory, the "Separation Wall" and movement restrictions imposed by Israeli authorities create barriers to the right to health for Palestinians and impede sustainability of quality healthcare services [35]. In 1993 the Palestinian Authority (PA), functioning through the Ministry of Health $(\mathrm{MOH})$, was established following the 1993 Oslo Peace Accords given responsibility for the administration of health care in the region. Although it continues functioning, the Israeli state retains control over the core domains of access to care - financing, movement, infrastructure, and pharmaceutical market, health workforce. The local health system demonstrates, therefore, limited access to care and remains reliant on humanitarian aid [36]. Therefore, high overall rate of UHC service coverage index in Israel - 82 [25] does not concern Occupied Palestinian Territories. As well, Israel neither passed legislation on Universal Health coverage [28], nor monitored the progress of their national health policy/strategy/plan towards Universal Health coverage [27], consequently, no information on health coverage of Palestinians can be retrieved and supported by Israely government commitments.

The Universal Health Coverage in these territories is in process as of 2020 with the support of other state parties with the WHO facilitation as there is neither policy implemented, nor basic health package defined [37].

In Ukraine 1,3 million were deemed in need and 1,3 million people's humanitarian needs for health were to be covered by the Humanitarian Response Plan in 2020 [38]. As of 2017 Ukraine did not monitor the progress of their national health policy/strategy/plan towards Universal Health coverage [27], but It has a relatively high overall rate of UHC service coverage index in - 68 [25].

A Public Health and a Health Financing Concepts for reducing high out-of-pocket expenditure and improving access to care were elaborated and approved in 2016, National Health Purchasing Agency and developing a State Guaranteed Benefit Package were established (40 (UHC Partnership, n.d.)). By then, Ukrainian governments passed legislation on Universal Health coverage [28]. However, Ukraine is the only country chosen for these analyses for which data on the discrepancies between overall health coverage and coverage of conflict-affected territories controlled by the recognized government from the point of view of the public sector health infrastructure [40].

We found it difficult to retrieve any solid data on the evolution of health systems in conflict-affected countries as well as information on approaches and results of recognized governments to ensure universal health coverage in conflict-affected zones governed by the de-facto government in situations of the ongoing crises. Reports given by humanitarian actors show gaps in health coverage, but not actually complement the overall data on countries given by other international agencies or demonstrate inequality between conflict-affected and peaceful parts of these countries. Consequently, the specific indicators of universal health coverage should be established to enable ev- idence-based government policymaking in fragile settings. Lack of governmental capacity and situations of externally driven health policy exacerbate the need for state-of-theart knowledge and recommendations to alleviate human suffering and maximize public good in a sustainable way.

\section{CONCLUSIONS}

Open-access sources let us draw only several conclusions on common features of real-life approaches employed by recognized governments to ensure health coverage of citizens, including the population of the disputed territories, struggling for independence.

Protracted nature of conflict leads to health system fragility resulting in adverse effects on conflict-affected population health coverage.

- Health policy in such settings is often externally driven due to lack of capacities of recognized government and reliance on external funding.

Safety and political concerns impede imposition of the context-specific durable solutions for the universal health coverage.

Recognized governments lack access to real data to perform evidence-based decision-making.

Conventional decision-making based on external demand leads to permanent underperformance of health governance.

\section{REFERENCES}

1. WHO, "Preamble to the constitution of the world health organization as adopted by the international health conference", New York, 19-22 June, 1946; signed on 22 July 1946 by the representatives of 61 States. Official Records of the World Health Organization. 2; 100. (in force on 7 April 1948).

2. WHO, UNICEF. Declaration on Primary Health Care; 2018 [cited 2021 Jan 17]. Available from: https://www.who.int/primary-health/conferencephc/declaration.

3. WHO. Primary Health Care, Fact sheet; 2019 [cited 2021 Jan 17]. Available from: https://www.who.int/news-room/fact-sheets/detail/ primary-health-care.

4. Diaconu,K.,etal.Understanding fragility:implications forglobal health research and practice, Health Policy and Planning; 2020 Mar 35; (2): 235-243.

5. Burkle, F. M Jr. Future humanitarian crises: challenges for practice, policy, and publichealth, Prehospital and disastermedicine;2010May-Jun;25(3):191-199.

6. Haar, R. J., Rubenstein L. S. Health in Postconflict and Fragile States (USIP Special Report 301); 2012 Jan [cited 2021 Jan 17]. Available from: https://www.usip.org/sites/default/files/SR_301.pdf

7. Melander, E. The UCDP Armed Conflict Definition; 2015 [cited 2021 Jan 17]. Available from: www.undp.org > dam > norway > img > sdg-16-0slo-2016

8. Wars in the World. List of ongoing Conflicts; 2020 Dec 22 [cited 2021 Jan 17]. Available from: https://www.warsintheworld. com/?page=static 1258254223

9. Uppsala Conflict Data Program. Countries in conflict view; 2019 [cited 2021 Jan 17]. Available from: https://ucdp.uu.se/encyclopedia

10. ICRC. Protracted conflict and humanitarian action: some recent ICRC experiences, International Committee of the Red Cross, Geneva; 2016 [cited 2021 Jan 17]. Available from: https://www.icrc.org/sites/default/ files/document/file_list/protracted_conflict_and_humanitarian_ action_icrc_report_Ir_29.08.16.pdf 
11. All Africa. Somalia: Islamic Party Insurgents Declare War on New Govt; 2009 Feb 7 [archived from the original 2012 0ct 7; cited 2021 Jan 17]. Available from: https://allafrica.com/stories/200902080003.html

12. United Nations. Report of the International Commission of Inquiry on Darfur to the United Nations Secretary-General; 2005 Jan 25; 129 [archived(PDF) from the original 2013 Sept 1; cited 2013 Aug 14].

13. BBC News. Donetsk 'people's republic' declared; 2014 Apr 7 [cited 2020 Apr 12]. Available from: https://www.bbc.com/news/worldeurope-26919928

14. Croissant, Michael P. The Armenia-Azerbaijan Conflict: Causes and Implications. London, Praeger; 1998. ISBN 0-275-96241-5

15. BBC News. A History of Conflict: Introduction. A History of Conflict. [cited 2021 Jan 17]. Available from: http://news.bbc.co.uk/2/shared/spl/hi/ middle_east/03/v3_ip_timeline/html/default.stm

16. Cameroon Journal. Explosions in Bamenda and Killings in Besongabang Military Base, ADF Claims Responsibility; 2017 Sept 13 [cited 2021 Jan 17]. Available from: http://cameroonjournal.com/2017/09/13/ breaking-news-explosions-in-bamenda-and-killings-in-besongabangmilitary-base-adf-claims-responsibility/

17. Ndi, Anthony. Southern West Cameroon Revisited (1950-1972): Unveiling Inescapable Traps. Langaa RPCIG; 2014.

18. Sullivan, Rory; Isaac, Lindsay. Azerbaijan and Armenia accuse each other of breaking ceasefire. CNN; 2020 0ct 11 [cited 2021 Jan 17]. Available from: https://edition.cnn.com/2020/10/10/europe/azerbaijanarmenia-ceasefire-intl/index.html

19. Melikyan A., Geybullaeva A. President of Azerbaijan tells Armenia to 'leave our territory, and then, the war will stop'. CNN; 2020 0ct 3 [cited 2021 Jan 17]. Available from: https://edition.cnn.com/2020/10/03/ asia/azerbaijan-armenia-president-intl/index.html

20. Humanitarian Coalition. What Is a Humanitarian Crisis. [cited 2021 Jan 17]. Available from: https://www.humanitariancoalition.ca/infoportal/factsheets/what-is-a-humanitarian-crisis

21. WHO. The World Health Organization Emergencies. [cited 2021 Jan 17]. Available from: https://www.who.int/emergencies/crises/en/

22. UN OCHA. Humanitarian response plan Somalia; 2020 Jan [cited 2021 Jan 17]. Available from: https://www.humanitarianresponse. info/sites/www.humanitarianresponse.info/files/documents/files/ somalia_2019_hrp_final.pdf

23. UNICEF, WHO. Essential Package of Health Services launched in Somalia to improve maternal and child health. Joint press release; 2014 May 7 [cited 2021 Jan 17]. Available from: https://reliefweb.int/report/ somalia/essential-package-health-services-launched-somaliaimprove-maternal-and-child-health

24. News Medical. Somalia aims to provide universal basic health care by 2016; 2013 Mar 25 [cited 2021 Jan 17]. Available from: https:// www.news-medical.net/news/20130325/Somalia-aims-to-provideuniversal-basic-health-care-by-2016.aspx

25. WHO. Global Health Observatory data repository. Index of service coverage. Data by country; 2020 0ct 13 [cited 2021 Jan 17]. Available from: https://apps.who.int/gho/data/node.main. INDEXOFESSENTIALSERVICECOVERAGE

26. MoPIED of Somalia. Somalia national development plan 2020 to 2024; 2019 [cited 2021 Jan 17]. Available from: http://mop.gov.so/wpcontent/uploads/2019/12/NDP-9-2020-2024.pdf

27. WHO. Health Systems Strengthening; 2017 [cited 2021 Jan 17]. Available from: https://www.who.int/data/gho/data/themes/topics/healthsystems-strengthening
28. WHO. Countries that have passed legislation on Universal Health Coverage (UHC); 2021 [cited 2021 Jan 17]. Available from: https://www. who.int/data/gho/data/indicators/indicator-details/GHO/countriesthat-have-passed-legislation-on-universal-health-coverage-(uhc)

29. UN OCHA. Humanitarian response plan Sudan; 2020 Jan [cited 2021 Jan 17]. Available from: https://www.humanitarianresponse.info/ sites/www.humanitarianresponse.info/files/documents/files/ sudan_2020_hrp.pdf

30. Wharton, G., et al. Rebuilding Sudan's health system: opportunities and challenges. The Lancet; 2020 Jan; 395(10219):171-173

31. UN OCHA. Humanitarian response plan Cameroon; 2020 Mar [cited 2021 Jan 17]. Available from: https://www.humanitarianresponse. info/sites/www.humanitarianresponse.info/files/documents/files/ cmr_hrp_2020_final.pdf

32. Haddison E. C., Julius C., Kagina B. Health Services Utilisation before and during an Armed Conflict; Experiences from the Southwest Region of Cameroon. The Open Public Health Journal; 2020 0ct; 13(1): 547-554; D0I: 10.2174/1874944502013010547 [cited 2021 Jan 17] Available from: https://openpublichealthjournal.com/VOLUME/13/PAGE/547/

33. WHO. Health Analytical Profile 2016 Cameroon; 2016 [cited 2021 Jan 17] Available from: https://reliefweb.int/sites/reliefweb.int/files/resources/ health_profile_cameroon_2016_eng.pdf

34. UN OCHA. Humanitarian response plan OPT; 2020 Jan [cited 2021 Jan 17]. Available from: https://www.humanitarianresponse.info/sites/ www.humanitarianresponse.info/files/documents/files/hrp_2020.pdf

35. WHO Regional Office for the Eastern Mediterranean. Right to Health in the occupied Palestinian territory: 2018. Cairo; 2018. Licence: CC BYNC-SA 3.0 IGO [cited 2021 Jan 17]. Available from: https://reliefweb. int/sites/reliefweb.int/files/resources/WHO_Right_to_health_2018_ Web-final.pdf

36. Efrat M. Divide and conquer: inequality in health. Ramallah, Palestine: Physicians for Human Rights Israel; 2015 [cited 2021 Jan 23]. Available from: http://www.scribd.com/doc/256771352/Divide-ConquerInequality-in-Health-PHR-Israel

37. WHO. Seventy-third world health assembly A73/15. Agenda item 17: Health conditions in the occupied Palestinian territory, including east Jerusalem, and in the occupied Syrian Golan. Report by the DirectorGeneral. 2020 Nov 5 [cited 2021 Jan 17]. Available from: https://apps. who.int/gb/ebwha/pdf_files/WHA73/A73_15-en.pdf

38. UN OCHA. Humanitarian response plan Ukraine; 2020 Jan [cited 2021 Jan 17]. Available from: https://www.humanitarianresponse. info/sites/www.humanitarianresponse.info/files/documents/files/ ukraine_2020_humanitarian_response_plan_en.pdf

39. UHC Partnership. Ukraine; n.d. [cited 2021 Jan 17]. Available from: https://www.uhcpartnership.net/country-profile/ukraine/

40. USAID. Zvit za rezultatamy analizu nadannia pervynnoi medychnoi dopomohy u vyznachenykh raionakh Donetskoi ta Luhanskoi oblastei [Report on results of survey of primary medical care in certain areas of Donetsk and Luhansk regions]. Proekt USAID «Pidtrymka reformy okhorony zdorovia». Kyiv; 2020.

The article was written in the frames of PhD thesis "Rebuilding and development of the primary healthcare system in postconflict settings".

\section{ORCID and contributionship:}

Mariia V. Yashchenko: 0000-0002-6161-3527 A, B, C,D

Tetiana P. Yurochko: 0000-0002-9455-9141 E,F 


\section{Conflict of interest:}

The Authors declare no conflict of interest.

\section{CORRESPONDING AUTHOR}

Mariia V. Yashchenko

Kyiv, Voloska street 10

tel: +380663724886

e-mail:m.yaschenko@ukma.edu.ua

Received: 27.11 .2020

Accepted: 30.03 .2021

A - Work concept and design, B - Data collection and analysis, C - Responsibility for statistical analysis,

D-Writing the article, $\mathbf{E}$-Critical review, $\mathbf{F}$ - Final approval of the article 